\title{
Residual effect of Organic Waste Amendment on Soil Productivity and Crop Yield -- A Review
}

\author{
NWEKE I. A.
}

Department of Soil Science Chukwuemeka Odumegwu Ojukwu University, Anambra State.

\section{ARTICLE INFO}

Article No.:090618129

Type: Review

DOI: 10.15580/GJAS.2018.9.090618129

\section{Submitted: 06/09/2018}

Accepted: 11/09/2018

Published: 29/09/2018

${ }^{\star}$ Corresponding Author

Nweke I. A.

E-mail: nweksoniyke@gmail.com

Keywords: Crop yield, organic waste, nutrient recycling.

\section{ABSTRACT}

Fallowing has been an efficient balance and sustainable crop production system for soil productivity especially for tropical soils. The sustainability of this soil management option in south east Nigeria has drastically reduced to almost zero, hence the use of external inputs in the form of organic waste has become imperative. Organic waste has been used as soil conditioner since ancient times and its benefits are yet to be fully realised in crop production activities. Organic wastes release nutrients slowly and steadily, improve soil nutrient status and recycling, activate soil microbes, soil physical attributes, crop yield and good fruits often reflected by consumers, public health and environmental harmony. This paper reviews various contributions of organic waste to soil productivity and crop yield and its possibility in sustaining crop production activities in tropical soil. 


\section{INTRODUCTION}

Agricultural sustainability by farmers is based on the continuous availability of plant nutrients in the soil. These nutrients as it where, are not always there, because of continuous cropping that leads to the depletion of soil nutrients and in extreme cases total loss of soil nutrients and this result in poor performance of the cultivated crops. Also increase in human population led to intensive cultivation of the limited arable land without adequately replenishing soil nutrients has contributed immensely to the depletion of resource base and decline in crop yields. The soil become fragile;quickly lose organic matter the store house of plant nutrients in the soil. Hence the nutrients are exposed to harsh environmental conditions and intensive cultivation that further accelerate the loss of the nutrients. Traditionally soil is a natural medium for organic waste disposal. The wastes enhance soil fertility and can improve or degrade the physical properties of soil. When these wastes are properly applied in soil and carefully monitored they supply the crop with needed nutrients and reduces the farmers cost of production. The understanding of the behaviour of nutrient elements in the soil-plant atmosphere is particularly important especially now that environmental quality and food production are of major concern. Mbagwu (1989) observed that soil differs in their response to organic waste amendments and that it is important to investigate more closely the influence of these wastes on a range of soil physical and chemical properties. Waste amended soils have been reported to have high organic matter soil content, influences soil aggregation and aggregate stability, reduce soil bulk density, increase total porosity and hydraulic conductivity (Nnabude et al., 2000; Nnabude and Mbagwu 2001; Nweke et al., 2014).

Organic matter is very important to changes in soil management; it represents an accumulation of partially synthesised plant and animal residues that are continually being broken down as a result of the activities of soil micro-organisms. Hence it is a transitory soil constituent and must be renewed instantly by the addition of organic wastes. Organic matter strongly influence soil structure, nutrient status and release, microbial population, increase the amount of water a soil can hold and proportion of this water available for plant growth and development. Soil organic matter content is an early indicator of overall soil quality especially in cultivated soils (Campell et al. 1998). Organic wastes are substances that consist of materials containing carbon compounds (Adediran et al., 2003). The carbon compound can come from either plants or animals that are biodegradable that supply nutrients to the plants or provides nutrients to plants without the contamination of soil chemical substances. They release nutrients after their decomposition. Organic wastes improve the soil physical, chemical and biological properties of the soil. Organic wastes release nutrients slowly and steadily and increase activities of soil microbial biomass (Ayuso et al.
1997; Belay et al. 2001); sustain cropping system through better nutrient recycle and improvement of soil physical attributes (El-Shakweer et al., 1998). Thus this review intended to $x$-ray various contributions of organic wastes to soil, crop yield and environmental health.

\section{Residual effect of organic waste amendments on crop yield and soil productivity}

Application of organic waste to the soil has been reported to influence soil properties and crop yield, Mbah et al. (2011) observed that land application of burnt, unburnt and mixtures and un-burnt rice mill waste improved soil physical properties and enhanced maize yield. While Nweke and Nsoanya (2013) and Nweke et al. (2014) observed improvement in soil chemical properties and grain yield of maize and cucumber with different rates application of rice mill waste and poultry manure respectively. Soil water content increases with increasing amount of residue in dry land cropping systems, and wheat stubble can save an additional $50 \mathrm{~mm}$ of water during the non-growing season (Nielsen 2006), soil bulk density has also been affected by crop residue, Shaver et al. (2002) found that as crop residue accumulation increased, soil bulk density decreased, thereby increasing soil porosity and the potential for water infiltration. Removal of crop residue reservoir of essential macro and micro nutrient pools and crop residues recycles SOM. Rate of residual removed, rate of residue decomposition, residue quality, rate of fertilizer applied, soil characteristics, and climate all affect the amount of nutrients depleted from the soil when residue is removed (Blanco and Lal 2009b), crop residue has also been tied to soil $\mathrm{pH}$, Blanco and Lal (2009) reported decrease in soil $\mathrm{pH}$ with increased crop residue. Murphy et al. (2007) observed that microorganism such as microalgae, actinomycetes bacteria and fungi, play important role in organic matter degradation, nutrient cycle and chemical transformation in soil. Also macro- organisms in soil such as earthworm play very good role in organic matter decomposition, nutrient release and cycle transformation, detoxification, soil aeration and erosion control (Nweke 2014; Nweke and Ogugua 2015), since carbon is used for energy by decomposers, its fate is to be either assimilated into their tissues, released as metabolic products or respired as $\mathrm{CO}_{2}$.

The macro nutrients $\mathrm{N}, \mathrm{P}$ and Sulphur, present in organic chemical structures are converted into inorganic forms according to Baldock and Nelson (2000) they are either immobilized and used in synthesis of new microbial tissues or mineralized and released into the soil mineral nutrient pool for assimilation by microorganisms of decomposing organic residues. Thus nitrogen has to be assimilated in an amount determinate by the $\mathrm{C} / \mathrm{N}$ ratio of the microbial biomass. In soil amended with compost or raw organic material, Ros et al. (2006) and Kaur etal. (2008) observed that in association with mineral fertilizer $\mathrm{N}$, microbiological 
activity and growth can be stimulated. Though they did suggest a direct effect is detectable from micro-organism introduced with the compost. Many long term studies have shown that biological properties, such as microbial biomass carbon, basal respiration and some enzymatic activities are significantly improved when compostis applied. This is evidently true of the upper layers of the soil because of the added labile fraction of OM, which is the most degradable one (Zaman et al., 2004; Ros et al., 2006a, b, Tejada et al., 2006, 2009). Decomposition of $\mathrm{OM}$ is chiefly carried out by heterotrophic microorganisms. The process is under the influence of temperature, moisture and ambient soil conditions and leads to the release and cycling of plant nutrients, especially nutrient N, Sulphur and Phosphorous (Murphy et al., 2007).

Tiltarelli et al. (2007) reported that the simplest method of assessing the agronomic value of stabilized organic materials is by calculating both organic matter supply and plant nutrients. The slow release of these nutrients influence crop yields in the subsequent years, thus the essence of evaluating the true agronomic value of these organic materials as amendments. Though there is a considerable variability between experimental techniques, climate, soil type and organic material characteristics, attention need to be paid to generalizing the effects of composts and raw waste application on the soil-crop system. In management practices soil biology and microbiological properties are very reactive to small changes that occur. Hence they are used in a simple analysis for determining the effects of different sources and amount of organic matter application on soil characteristics during field experiments. Soil organisms such as bacteria, fungi, actinomycetes and microalgae the amount of $\mathrm{N}$ required by these organisms is 20 times smaller than that of $\mathrm{C}$. There will be net $\mathrm{N}$ mineralization with release of inorganic $\mathrm{N}$ in low concentration of easily decomposable $\mathrm{C}$ compounds and a larger $\mathrm{N}$ quantity in respect to that required by the microbial biomass. If the amount of nitrogen $(\mathrm{N})$ present in the organic residues is smaller than that required by the microbial biomass, Corbeels et al. (1999) found that inorganic $\mathrm{N}$ will be immobilized from the soil in order to complete the decomposition process.

The liberation of plant nutrients on continuous bases for longer periods of time, compared with mineral fertilizers can sustain by the microbial biomass population as the composts are slowly decomposed in the soil (Murphy et al., 2007). In many field trials after their application interesting residual effect of composts, which also results in a longer availability of plant Nutrients on the microbial activity has often been observed. For example, Ginting et al. (2003) found that 4 years after the last application of compost and manure that the residual effects on soil microbial biomass $\mathrm{C}$ increased from 20 to $40 \%$ higher compared with the $\mathrm{N}$ fertilizer treatment. The effect of different doses of raw municipal solid waste in Mediterranean semi-arid conditions was studied by Bastida et al. (2008) the doses studied range between 65 and 260 tha $^{-1}$ after 17 years a single dose application of this organic amendment was observed to increase of $70 \%$ in organic matter content and water- soluble carbon fractions increased up to 195 tha $^{-1}$ application rate, above which they levelled off. Bastida and his companions equally observed that soil biochemical qualityis improved and that the enzymatic activities of O-diphenyloxidase, alkaline phosphatise urease and $B$ - glucosidase associated with humic substances increased significantly in all the amended plots. Site-specific factors such as climate, soil properties, compost matrices, composting conditions, and management practices can affect the $\mathrm{N}$ dynamics in compost-amended soils. Thus prompt availability of $\mathrm{N}$ to plants is low since the majority of total compost $\mathrm{N}$ according to Amlinger et al. (2003) is bound to the organic $\mathrm{N}$-pool. In fact, the greatest total $\mathrm{N}$ content in compost is not readily available, but it can be mineralized and consequently peaked up by plants, denitrified and/or leached or immobilized.

It is necessary to under note that the slow release of nutrients from compost or green manures should be effectively controlled to match temporal crop demand with nutrient supply. Blackshaw et al. (2005) in a 4-year experiment observed rang of 26 to 67 and from 12 to $18 \mathrm{kgha}^{-1}$ for fresh and stabilized manure respectively, while the amount of $\mathrm{N}$ used by crops from municipal solid waste compost for barley, wheat and canola, at two different sites, as reported by Zhang et al. (2006) was $11,3,1$ and $2 \%$ for the first and subsequent 3 years. The report of Bastida and Zhang indicate the complexity of estimating $\mathrm{N}$ released from different composts and its relationship with plant $\mathrm{N}$ uptake. In 7 years experiment on one time food waste compost application Sullivan et al. (2003) found consistently increased $\mathrm{N}$ uptake by a total of 294 to $527 \mathrm{~kg} \mathrm{ha}^{-1}$ and compost $\mathrm{N}$ immobilization/ mobilization are closely associated with the degradability and balance of soil $\mathrm{C}$ pools. When lowest rate of $P\left(125 \mathrm{kgha}^{-1}\right)$ was applied for the annual P-based beef cattle manure and the greatest amount $594 \mathrm{kgPha}^{-1}$ was applied for the biennial $\mathrm{N}$-based cattle manure compost treatment Eghball et al. (2004) observed the latter resulted in $\mathrm{P}$ leaching to a soil depth of 45 to $60 \mathrm{~cm}$. They however observed from their result that the P-based application was environmentally good, since it provided nutrients for the plant, while maintaining the amended soil $P$ at a level similar to the untreated control. According to the studies of Lal (2006) three possible relationships exist between agronomic productivity or crop yield to organic $\mathrm{C}$ content of soil and they are; increase in crop yield with decrease in the organic carbon pool, no or little decrease in crop yield with reduction in the organic carbon pool and increase in crop yield as a consequence of organic carbon pool enhancement.

The conflicting, responses however may depend on specific factors like soil management, use of mineral fertilizers, organic amendments and previous organic carbon pool. As demonstrated by several long-term studies on crop nutrition and yield responses, the benefits of increased organic matter content differed on 
the basis of the rate supplied. For instance Hartl et al. (2003) in a 5-year trial, found out that spreading of 40 tha $^{-1}$ bio waste compost, from source-separated organic household waste and yard trimmings, every second year lead to slight increase (9\%) in rye yields than other rates. This report simple suggest that beneficial use of compost depends on choosing the best amount and frequency of compost application. application in provide slow-release $\mathrm{N}$ for plant growth, over a 7-year period as was reported by Sullivan et al. (2003) in a long-lasting effect of a one-time high rate $\left(155 \mathrm{t} \mathrm{ha}^{-1}\right)$ food waste compost. The findings from their work however agreed with the report of Habteselassie et al. (2006), who noted that soils with about 100 tha $^{-1}$ dairy waste compost maintained $\mathrm{N}$ supply to the crops through continuous mineralization. When a high rate $\left(80\right.$ tha $\left.^{-1}\right)$ of municipal solid waste compost was applied annually over 5 years, alone or combined with mineral fertilizer, reaching 60.2 and 61.9 tha $^{-1}$, respectively Cherif et al. (2009) observed that wheat grain yield was improved by $246 \%$, in respect to the control. Erhart et al. (2005) evaluated the agronomic performance of bio waste compost, on cereals and potatoes and reported that the highest application rate equal to 23 tha $^{-1} y e a r^{-1}$ increased crop yields by $10 \%$ compared with the unfertilized control, on the average of 10 years. The use of composts or other organic amendments in combination with mineral fertilizers as revealed by Ros et al. (2006a) and Bi et al. (2008) improved crop yield in many cropping systems over more than 10 years, compared with compost and amendments alone.

Furthermore, Kaur et al. (2008) found highest maize grain yield where farmyard manure at $10 \mathrm{t}$ ha- ${ }^{1}$ was applied along with recommended NPK fertilizer for 34 years, under a maize-wheat cropping system. In a 7year experiment of vegetable-fruit-garden-waste compost combined with cattle slurry applied at both 22.5 tha $^{-1}$ yearly and 45 tha $^{-1}$ every other year, Leroy et al. (2007) reported that both applications methods led to higher maize yields (25 to 43\%) in respect to the individual application of the two organic amendments.

The work of Butler and Muir (2006) on compost reported highest tall wheat grass dry matter yield with the highest compost application of diary manure rate of about 150tha ${ }^{-1}$. The wheat grass yield increased from 32 to $96 \%$ with 11.2 and 179.2 tha $^{-1}$ compost respectively, in the first of two cropping seasons. In terms of sustainability, Nardi et al. (2004) found out that only farmyard manure application maintained in the total organic carbon level of 40 tha $^{-1}$ measured in the top soil layers at the start of a 40-year study and that the average total organic C depletion was $23 \%$ with liquid manure and mixed application treatment, $43 \%$ with chemical fertilizer alone and $51 \%$ in the control. The pressure of weekly acidic spreading in the first year of application noted by Hartl et al. (2003) and Eghball et al. (2004) can be an estimation of the available $\mathrm{N}$ from compost treatment. Tiltarelli et al. (2007) reported release of only $30-35 \%$ of the total $\mathrm{N}$ content. With higher rates Zhang et al. (2006) noted that the $\mathrm{N}$ release from compost mostly occur in the first two years after application, of which suggested that a distribution frequency of once in every second year may be better than other application strategies.

It is well known facts that most soil microorganisms convert organic $\mathrm{N}$ into inorganic $\mathrm{N}$ forms by mineralization. Many authors have confirmed that in the short-term, $\mathrm{N}$ mineralization from compost is very limited. However the work of Eghball (2002) and Leroy et al. (2007) showed that residual effect from the cumulative application becomes visible after 4-5 years, in higher N availability and yields. Garcia-Gil et al. (2004) found out that regular addition of organic material to soil for more than 10 years, through compost or manures, improved soil carbon and $\mathrm{N}$ stock. This resulted in buildup of $\mathrm{N}$ which shows physical protection of these nutrients chemical functional groups on organic molecular that makes organic matter an effective buffer. With long-term compost use it was widely reported that the residual effects on crop production and soil properties last for several years; since only a fraction of the $\mathrm{N}$ and other nutrient becomes available for crop uptake in the first year within macro aggregate (Whelei and Chang 2002, Meng et al.,2005; Mallory and Griffin 2007, Sodhi et al., 2009). The organic N in upper $30 \mathrm{~cm}$ of soil after 10 years of compost treatments was evaluated by Harti and Erhert (2005). Their result indicated significant increases in organic $\mathrm{N}$ of $22 \%$, showing that the organic $\mathrm{N}$ was tied up in organic matter. After 4 years of vegetable compost application Nevens and Reheul (2003) reported significantly higher total N concentration on compost plots compared with plots without compost. The $\mathrm{C} / \mathrm{N}$ ratio of organic material is a good indicator of nutrient supply. For soil amended with compost originating from leguminous residues Tejade et al. (2009) observed optimum balance $\mathrm{C} / \mathrm{N}(10-12)$ one to organic matter mineralization overcoming immobilization. However their result was not in tandem with those of Weber et al. (2007), who observed increased the $\mathrm{C} / \mathrm{N}$ ratio from 10.7 up to 22.2, in the third year after municipal solid waste compost application. This characteristic may be explained by a depletion of $\mathrm{N}$ reserve, probably due to crop $\mathrm{N}$ uptake. There other explanations however on such increase in the $\mathrm{C} / \mathrm{N}$ ratio because Amlinger et al. (2003) found out that when compost with a high $\mathrm{C} / \mathrm{N}$ ratio is added to soil, the microbial population compete with plants for soil N, thus immobilizing the $\mathrm{N}$.

Water resistant aggregate stability of the soil in the terraces is increased when organic residues are used. In these terraces, Querejeta et al. (2000) observed that the water holding capacity, plant available water and hydraulic conductivity increased compared to terraces in which no organic amendments is used, whereas the volume weight decreases. The dilution effect of the added organic matter with the denser mineral fraction induce soil bulk density decrease and influenced soil aggregation, this according to Gammier et al. (2004) can lead to greater porosity. The use of organic treatment in tea cultivation site increased the soil water stable 
aggregates (Campell et al., 2001). Cheny et al. (2000) reported a positive correlation between soil organic matter and aggregates stability. Soil compaction caused by human trampling, wheel traffic or animal grazing were found by Drewet and Paton (2005) to destroy soil large pores and reduce saturated or near-saturated hydraulic conductivity. Ruan et al. (2001) worked on effect of residue cover and associated surface sealing on two dimensional infiltrations, he and companions observed crop residue cover to occur in distinct, regular patches beneath which the hydraulic conductivity of the surface soil was maintained at its original value, and bare soil were assumed to seal to various fractions of the saturated hydraulic conductivity. Baziramakenga et al. (2001) and Guisquiani et al. (1995), have all found increased soil water holding capacity after application of urban waste. Urban waste compost has been shown to increase total porosity (Guisquiani et al., 1995; Aggelides and Londra 2000), porosity is a measure of the size and arrangement of voids in the small matrix, and thus affects both aeration and water movement. In addition to increase total porosity, compost application can change pore size distribution. Guisquaini et al. (1995) found that stability of the pore system was increased linearly with compost application rates. Mbah et al. (2004) observed that bulk density relates to root penetration, soil strength and compaction. The problem associated with high bulk density as soil compacting include, tillage, poor root penetration, reduced porosity, reduce water infiltration into the soil and reduced water movement into soil, low bulk density in association with low traffic ability, low traction, leaching and poor anchorage. Ogunwole (2005) Ogunwole and Ogunleye (2004) reported the lengthen studies in Nigeria have shown consistently the fit of organic manure and chemical fertilizers in sustaining and improving organic matter in soil. Organic matter input such as green and farmyard manure, crop residues provide short term of nutrient supply. The recycling organic inputs through their disposal on cultivated land for production is a good soil fertility management strategy the standpoint of improving soils productive capacity and reduced dependency on mineral fertilize. This is a crucial soil property affecting soil sustainability and crop production. Gosling and Shepherd (2005), found no statistical significant difference between conventional land management's and organic matter for aggregate stability. The protective nature of clayey soil, which reduces the amount of decomposition cause significant difference related to land use. The breakdown of aggregate may result from a variety of physical and physiochemical mechanism like slaking, break down by differential swelling during fast wetting by impact of rain drop and also physiochemical dispersion due to osmotic stress upon wetting with low electrolyte water with each mechanism differing in the type of energy involved in aggregate disruption, in the size distribution of disrupted product and also in type of soil properties affecting the mechanism (Amezketa 1999).

Bazzoffi et al. (1998) showed that urban refuse compost increased soil bulk density although Giusaquiani et al. (1995) found that bulk density was reduced by municipal sludge compost and urban waste compost respectively. Zebarth et al. (1999) applied six different organic amendments including bio-solids and food waste compost and found that all the materials reduced bulk density. A decrease in bulk density might be expected when soil is mixed with less dense organic material, but there may also be associated changes in soil structure. The magnitude of change for bulk density and other soil properties is likely to differ with soil texture as noted by Aggelides and Londra (2000). Reduced penetration resistance as a result of compost use is also commonly reported (Aggelides and Londra 2000) low soil penetrometer readings indicated more favourable conditions for root growth, Similarly, Bazzoffi et al. (1998) found that compost could prevent increased penetration resistance under many trafficking. Many studies have addressed the effects of compost and manures on aggregate stability although it is often difficult to compare results due to the use of different assessment methods (E.g. water stable aggregate or benzene stable aggregated) and also the information provided about application rates. Paper sludge has generally been shown to have a positive effect on aggregation (Nematic et al., 2000). Nematic et al. (2000), compared composted and uncomposted paper sludge and composted municipal wastes on aggregation stability have shown positive (Aggelides and Londra 2000; Albiach et al., 2001). Carter and Gregorich(1996) reported that turnover time of organic matter in aggregate could be much longer than that of litter remained without aggregation. Organic carbon in intramicro aggregate has longer turnover time than intermicro aggregate which can be characterized by both relatively short-term storage in microaggregates or longterm sequestration in microaggregate. In order words, organic matter or fractions thereof are basic to the aggregation process and consequently organic matter sequestered within aggregates is protected against degradation, Carterand Gregorich (1996), was of the view that aggregates resulted from the above various process and cementing agents, however, could be broken down during natural and artificial stress such as erosion and tillage, subsequently organic matter sequestered in them can be decomposed. Denefet al. (2001) and Sixet al. (2009) said actually, macroaggregate have their own life cycle, repeating formation breakdown depending on biological activity and fresh residue inputs.

\section{CONCLUSION}

Organic wastes contain valuable nutrients that promote crop growth, yield and environmental health. Both macro and micro-nutrients and other growth promoting substances are present in the wastes in various proportions that however depend on the type of waste. Organic wastes are mainly from animal and agricultural 
wastes. With the increase in population that demand increase in food production and rise in demand of organic food crops, organic wastes becomes an ideal input for the farmers as it will supply plant nutrients and other soil stimulants for crop growth and yield, soil quality and public health. Hence it becomes important to establish the ideal rate of application of organic wastes in order to achieve this noble objective.

\section{REFERENCES}

Adediran J A, Taiwo L B and Sobulo R A (2003). Organic wastes and their effect on tomato (Lycoperi con esculentum) yield Agr. Soils 33: 99116

Aggelides, S.M. and Londra, P.A. (2000). Effect of compost produced from town wastes and sewage sludge on the physical properties of a loamy and a clay soil. Bio. Resource Technology, 71:253-259.

Albiach, R., Canet, R., Pomares, F. and Ingelmo, F. (2001). Organic matter components and aggregate stability after the application of different amendments to a horticultural soil, Bio. Resource Technol. 76:125-129.

Amezquita, E., Barrios E., Rao, I.M., Thomas, R., Sanz; J.I., Hoyos, P., Molina, D. (1999). Soil physical conditions different tillage and management system to construct an arable layer. In: PE 2 Staff (eds), PE-2 annual report 1999, International Centre for tropical Agriculture, Cali pp 53-55.

Amlinger, F., Gotz, B., Dreher, P., Geszti J., and Weissteiner, C. (2003). Nitrogen in biowaste and yard waste compost: dynamics of mobilization and availability-a review, J. Soil Biol. 39; 101-116.

Ayuso M A, Pascal J A, Garcia C and Hermandez T (1997). Evaluation of urban wastes for urban agricultural use. Soil Sci. Plant Nutr. 22: 105-111.

Baldock, J.A. and Nelson, P.N. (2000). Soil organic matter, In: Summer, M.E. (ed). Handbook of soil science, CRC press.

Bastida, F., Kandeler, E., Hernandez, T., and Garcia, C. (2008). Long-term effect of municipal solid waste amendment on microbial abundance and humus-associated enzyme activities under semiarid conditions, Microbial Ecol. 55:651-661.

Baziramakenga, R., Simard, R.R. and Lalaude, R. (2001). Effect of de-inking paper sludge compost application on soil chemical and biological properties. Can. J. Soil Sci. 81: 561-575.

Bazzoffi P, Pellegrini S, Rochini A, Morandi M, and Grasselli O. (1998). The effect of de-inking paper sludge compost application on soil chemical and biological properties, soil erosion and maize yield. Soil Till. Res. 48: 275-286.

Belay A, Classen A S, Wehner F C and Bee J M (2001). Influence of residual manure on selected nutrient elements and microbial composition of soil under long term crop rotation. Afri. J. Plant Soil 18: 1-6

Bi, L., Zhang, B., Liu, G., Liu, Y., Ye, C. Yu, X., Lai, T. Zhany, J, Yin, J. and Liany, Y. (2008). Long term effects of organic amendment on the rice yields for double rice cropping systems in subtropical China. Agr. Ecosyst. Environ. DOI 10.1016/Jagec. 2008, 11.007.

Blackshaw, R.E., Molnar, L.J. and Larney, F.J. (2005). Fertility, manure and compost effect on weed growth and competition with winter wheat in western Canada, Crop Port. 24:971-980.

Blanco-Conqui, H. and Lal, R. (2009). Corn stover removal for expanded uses reduces soil fertility and structure stability, SSSAJ. 73(2): 418-426.

Butler, T.J. and Muir, J.P. (2006). Diary manure compost improves soil and increase tall wheat grass yield. Agron. J. 98: 1090-1096.

Campbell C A, McConkey B E Biederbeck V O, Zenter R P and Peru M R (1998). Long-term effects of tillage and fallow-frequence on soil quality attribute in a clay in semi-arid south western Saskatcharan, Soil Till. Res. 46: 136-144.

Campbell, C.A.; Belles, F., Lafond, G.P; Biederbeck, V.O. and Zenter, R.P. (2001). Tillage-fertilizer changes: Effect on some soil quality attributes under long-term crop rotations in a thin black chenozem. Can. J. Soils Sci. 81:157-166.

Carter, M.R. and Gregorich, E.G. (1996). Methods characterize and quantify organic matter storage in soil fractions and aggregate. In: MR Carter and B.A. Steward (ed), structure and organic matter storage in agric. soil. Lewis Publ., CRC Press Boca Raton, FL. Pp449-466.

Cheny, C., le Bissonnais, Y. and Anouagas, D. (2000). Organic matter influence on clay wettability and soil aggregate stability. Soil Sci. Soc. Am. J. 64; 1475-1486.

Cherif, H., Ayari, E., Onzari, H., Marzoati, M., Brusetti, L., Jedidi, N., Hassen, A. and Daffonchio D. (2009). Effects on municipal solid waste compost farming and manure and chemical fertilizers on wheat growth, soil composition and soil bacterial characteristics under Tunisian arid climate, Eur. J. Soil Biol. 1-8.

Corbeels, M., Hofman, G., and Cleemput, D.V. (1999). Simulation of net $N$. immobilization and mineralization in substrate amended soils, Biol. Fertilize soils, 28: 422-430.

Denef, K.J., Six, J. Paustian, K., Merckx, R. (2001). Importance of microaggregates dynamics in controlling soil carbon stabilization: short-term effects of physical disturbance inducing by dry-wet cycle, Soil Biology \& Biochemistry 33:2145-2153.

Drewet. J.J. and Paton, R.J. (2005). Soil physical quality under cattle grazing of a winter-fed Brassica crop. Aust. J. Soil, Res. 43(4): 525-536.

Eggball, B. (2002). Soil properties as influenced by phosphorous and nitrogen based manure and compost applications, Agron. J. 94:128 - 135. 
Eghball, A., Ginting, D. and Gillery, J. (2004). Residual effect of manure and compost application on corn production and soil properties, Agron. J. 96: 442-447.

El- Shakweer M H A, El-Sayad E A, and Ewees M S A (1998). Soil and plant analysis as a guide for interpretation of the improvement efficiency of organic conditioners add to different solid in Egypt, Communication in Soil Science and Plant Analysis 29: 2067- 2088.

Erhart, E., Hart, W. and Put, B. (2005). Bio-waste compost affect yield nitrogen supply during the vegetation period and crop quality of agricultural crops. Eur. J. Agron. 23: 305-314.

Gamnnier, P., Ezine, N. DeGryze, S., and Richards, S. (2004). Hydraulic properties of soil-straw mixtures, Vodose zone J. 3: 714-721.

Garcia-Gil, J.C., Ceppi, S.B., Velasco, M.I., Polo, A. and Senesi, N. (2004). Long-term effects of amendment with municipal solid waste compost on the elemental and acidic functional group composition and pH-buffer capacity of soil humic acids, Geoderma, 121: 135-142.

Ginting, D., Kessavalou, A., Eghball, B., and Doran, J.W. (2003). Green house gas emissions and soil indicators four years after manure and compost applications, J. Environ. Qual. 32: 23-32.

Gosling P and Shepherd M (2005). Long term changes in soil fertility in organic arable farming system in England with particular reference to phosphorous and potassium, agriculture, Ecosystem and Environment, 105.

Guisquiniani, P.L., Palglial, M., Giglootti, G., Businell, D. and Benelti, A. (1995). Urban waste compost: effects on physical, chemical and biochemical soil properties. J. Environ. Qual. 24: 175-182.

Habteselassie, M.Y., Miller, B.E., Thacker, S.A. Stark, J.M. and Norton, J.M. (2006). Soil nitrogen and nutrient dynamics after repeated application of treated diary waste application, Soil Sci. Soc. Am. J. 70: 1338-1348.

Hartl, W. and Erhart, E. (2005) Crop nitrogen recovery and soil nitrogen dynamics in a 10 year field experiment interbiowaste compost; J. Plant Nutr. Soil Sci. 168: 781-788.

Hartl, W., Ptz, B., and Erhart, E. (2003). Influence of rates and timing of biowaste compost application on rye yield and soil nitrate levels, Eur. J. Biol. 39: 1239-139.

Kaur, T., Brar, B.S., and Drillon, N.S. (2008) Soil organic matter dynamics as affected by long-term use of organic and inorganic fertilizer under maize - wheat cropping. System, Nutr. Cycle Agroecosyst. 81:59-69.

Lal, R. (2006). Enhancing crop yield in the developing countries through restoration of soil organic carbon pool in agricultural land. Degrade.Dev; 197 $-209$.

Leroy, B.L., Bommole, M.M., Rehual, D., Moens, M., De Nve, S. (2007). The application of vegetable fruit and garden waste compost in addition to cattle shing in a silage maize mono culture. Effects on soil farming and yield, Eur. J. Soil Biol.43:91-100.

Mallory, E. B. and Griffin, T.S (2007). Impacts of soil amendment, history of nitrogen availability from manure and fertilizer, Soil Sci, Soc. Am. J. 71:964 $-973$

Mba C N, Mbagwu JSC, Onyia V N and Anikwe M A N (2004). Effect of application of biofertilizer on soil densification, total porosity, aggregate stability and maize grain yield in a dystric leptosol at Abakaliki-Nigeria J. Sci. Tech. 10: 74-85.

Mbagwu J S C (1989). Influence of cattle feed lot manure on aggregate stability, plastic limit and water relations of the soil in north- central Italy. Biological Waste 28: 257-267.

Mbah, C.N., Njoku, C., Idike, F.I. and Ezike, K.N.N. (2011). Potentials of rice wastes as soil amendment: Part I: Effect on soil properties and maize (zea mays) yield. Jour. Agric. Biol. Sci. 2(3):054-058

Meng, L., Ding, W. Cai, Z. (2005) Long-term applicationof organic manure and nitrogen fertilizer on $\mathrm{NO}_{2}$ emissions, Soil quality and crop production in a sandy loam soil, Boil. Biochem 37:2037 - 2045

Murphy, D.V., Stockdale E., A., Brookes, P.C. and Goulding K.W.T. (2007). Impact of microorganisms on chemical transformation in soil, In: Abbot, L.K., Murphy D. V. (eds) Soil biological Fertility - A key to sustainable land use in Agriculture, Springer, PP. 37 - 59.

Nardi, S., Morari, F., Berti, A., Tosoni, M. And Giardini. (2004). Soil organic matter properties after 40 years of different use of organic and mineral fertilizers. Eur. J. Agnon. 21:357 - 367.

Nematic, M.R., Canon, J. and Galichand, J. (2000). Stability of structural form during infiltration: Laboratory measurement on the effects of delinking sludge. Soil Sci. Soc. Am. J. 64:543 - 552.

Nevens, F. and Reheul, D. (2003). The application of vegetable, fruit and garden waste compost in addition to cattle slurry in a silage maize monoculture: nitrogen availability and use. Eur. J. Agron. 19:189-203.

Nielsen, D.C. (2006). Crop residue and soil water. In proceedings central plains irrigation conference Col by Kans: Central Plains.

Nnabude P C, Agunwamba J C, Mbagwu J S C (2000). Modelling infiltration rate in conditioned soil: Comparisons and modification Int. Agrophys. 14: 393-400

Nnabude, P.C. and Mbagwu, J.S.C. (2001). Physicochemical properties and productivity of a Nigerian typic Haplustult amended with fresh and burnt rice mill rice wastes. Bioresource Technology 36:265 272.

Nweke, I. A. (2014). Plant nutrient release composition in vermicompost as influenced by 
eudrilus egenae using different organic diets. J. Ecol. Nat. Envt. 5(11): 346-351.

Nweke, I. A., and Nsoanya, L. N. (2013). Effect of different rates of rice mill waste on soil chemical properties and grain yield of maize (zea mays L.), J. Agric. Rur. Dev. 16(1): 1431-1436.

Nweke, I. A., and Ogugua, Udoka V. (2015). Assessment of physico-chemical properties under contrasting earthworm (keffia Nigeriense) management practices, British J. Res. 2(1): 077085.

Nweke, I. A., Okoli, P. S. O., and Enyioko, C. O. (2014). Effect of different rates of poultry droppings and plant spacing on chemical properties and yield of cucumber, Elixir Agric. 70(2014): 23934-23940.

Ogunwole, J.O. and Ogunleye, P.O.(2004). Surface soil aggregation, trace and heavy metal enrichment under long- term application of farmyard manure and mineral fertilizers, Communications Soil Science Plant Analysis, 35:1055 -1516.

Ogunwole, J.O.(2005). Changes in alfisol under longterm application of manure and inorganic fertilizer. Soil Use Management, 21:260-261.

Querejeta, J.I., Rolda, N.A., Albaladefo, J. and Castillo, V. (2000). Soil physical properties and moisture content affected by site preparation in the afforestations in a semi- arid range land. Soil Sci. Soc. Am. J. 64:2087-2066.

Ros, M. Klammer S., Knapp, B. Aichberger K., and Insam H. (2006a). Long- term effects of compost Amendment of soil on functional and structural diversity and microbial activity, Soil Use Manage. 22;209-215.

Ros, M., Pascual, J.A. Garcia, C., Hamandez, M.T., and Insam, H. (2006b). Hydrolase activities, microbial biomass and bacterial community in a soil after long- term amendment with different composts, Soil Biol. Biochem. 32:3443-3452.

Ruan, H.X; Ahuja, L.R., Green, T.R. and Benjamin, J.A. (2001)., Residue cover and surface sealing effects on infiltration; numerical simulations for feud applications. Soil Sci. Soc. Am. J. 65 (3): 853-861.

Shaver, T.M., Peterson, G.A., Ahuja, L.R., West fall, D. G., Sherrod, L.A. and Dimm, G. (2002). Surface soil physical properties after 12 years of dry land no till management SSSAJ. 66(4)1296-1303.
Six, J., Merckx, R., Kimpe, K., Paustion, K. and Elliot, E.T. (2006). A revaluation of the enriched labile soil organic matter fraction Eur. J. Soil Sci. 51:283-293.

Sodhi, G.P.S., Beri, V. and Benbi, D.K.(2009). Soil aggegatiion and distribution of carbon and nitrogen in different fraction under long - term application of compost in rice wheat system. Soil Till. Res. DOI, 10.1016/J. Still.2008.12.005.

Sullivan, D.M., Bary, A.I., Nartes, T.J., Myrhe, E.A., Cogger- Fransen, S.C. (2003). Nitrogen availability seven year after a high rate food waste compost application, compost Sci. Util.11:265275.

Tejada, M., Garcia, G., Gonzalez, J.L. and Hermandez, M.T. (2006). Organic amendment based on fresh and composted beet. Vinesse: Influence on soil properties and wheat yield, Soil. Sci. Am. J. 70:900 - 908.

Tejada, M., Hermandez, M.T. and Garcia, C. (2009). Soil restoration using composted plant residues: effects on soil properties. Soil tillage Res. 102:109 $-117$.

Tittarelli, F., Petruzzelli, G., Pezzarossa, B., Civilini, M., Benedeti, A. and Sequi, P. (2007). Quality agronomic use of compost. In: Diaz, L.F., De Bertold, M., Bidlingmaier, W., Stentiford, E. (eds), Compost Science and Technology, Waste Management Series 8, Elsevier Ltd., pp. 119 145.

Whalen, J. K. and Chang, C. (2002). Macro-aggregate characteristics in cultiviated soils after 25 years annual manure applications. Soil Sci. Soc. Am. J. 66:1637 - 1647.

Zaman, M., Matushoria, M., Chang, S.X. Inubushi, R., Nguyen, L., Golo, S.., Kaneko, F. and Yoneyama, T. (2004). Nitrogen mineralization, $\mathrm{N}_{2} \mathrm{O}$ production and soil microbological properties of sewage sludge compost, Biol. Fert. Soils 40:101-109.

Zebarth, B.J., Neilsen, G.H., Hogue, E. and Neilsen, D (1999). Influence of organic waste amendments on selected soil physical and chemical properties. Canadian Journal of science 79:510-504.

Zhang, M., Heaney D., Henriquez, B., Solberg E., and Bitter $E$ (2006). A four year study on influence of biosolids/MSW compost application in less productive soil in Alberta: Nutrient dynamics. Compost, Sci. Util.14:68-80. 